\title{
Vulnerabilities of the European Union's Economy to Hydrological Extremes Outside its Borders
}

\author{
Ertug Ercin ${ }^{1,2,3, *}$, Daniel Chico ${ }^{4}$ and Ashok K. Chapagain ${ }^{5}$ \\ 1 R2Water Research and Consultancy, 1016 SG Amsterdam, The Netherlands \\ 2 Institute for Environmental Studies, Vrije Universiteit Amsterdam, 1081 HV Amsterdam, The Netherlands \\ 3 Water Engineering and Management, University of Twente, 7522 NB Enschede, The Netherlands \\ 4 Carbon Disclosure Project (CDP), London EC3R 5AD, UK; dani.chico@gmail.com \\ 5 Agricultural Economics, University of the Free State, Bloemfontein 9300, South Africa; \\ chapagainak@ufs.ac.za \\ * Correspondence: ercin@r2water.nl; Tel.: +31-61-736-6472
}

Received: 27 August 2019; Accepted: 27 September 2019; Published: 2 October 2019

check for updates

\begin{abstract}
Climate change is leading to increased water scarcity and drought in many parts of the world. This has implications for the European Union (EU) because a lot of the water intensive goods consumed or used there are produced abroad. This makes the EU's economy dependent on water resources well beyond its borders since when a country imports water intensive goods, indirectly it also imports virtual water (water needed to produce the imported goods). This study maps the EU's global dependency on water resources outside its borders in terms of virtual water imports and assesses how water scarcity and drought may disrupt supplies of key food crops that it imports. The EU uses approximately $668 \mathrm{~km}^{3}$ of water for all of the goods it produces, consumes and exports, annually. Around $38 \%$ of that water comes from outside its borders, which means that the EU's economy is highly dependent on the availability of water in other parts of the world. In the near future, supplies of certain crops to the EU could be disrupted due to water scarcity in other parts of the world; a large portion of the water used in producing soybeans, rice, sugarcane, cotton, almonds, pistachios and grapes for import to the EU comes from areas with significant or severe levels of water scarcity. Although the immediate risks to the EU's economy are due to current water scarcity levels, any disruption to rainfall patterns that occur in the future, due to the effects of climate change in the countries of origin of key crops, could have a far greater impact. This is because as much as $92 \%$ of the EU's total external water demand from agriculture is attributed to green water use, availability of which has relatively higher vulnerability to drought.
\end{abstract}

Keywords: remote vulnerabilities to hydrological extremes; virtual water trade; water footprints; drought severity; water scarcity

\section{Introduction}

Water, like energy, is a key input into any economy. With variations in water availability and quality from country to country, water impacts are mostly felt at the local scale [1]. At the same time, because goods are traded internationally to meet the needs of the world's populations, water is a global resource and, thus, a global issue. International trade in commodities implies long-distance transfers of water in virtual form, where "virtual" water is understood to be the volume of water that has been used to produce a commodity and that is, thus, virtually embedded in it [2]. Knowledge about the virtual water flows entering and leaving a region can cast a new light on the meaning of water dependencies of a region's economy, and on its susceptibilities outside its borders. 
The impact of hydrological extremes, for instance droughts, can affect economic activities, trade patterns and ecological systems that depend on the availability of water [3]. For example, lack of water can often result in losses of yields in both crop and livestock production and shift in production patterns that in turn, may affect trade flows of agricultural production [1]. Production losses, combined with changes in demand for products by different economic sectors, may lead to local shortages of certain goods, and thus result in the need to import those goods from other regions. However, the availability of those imports, particularly those that require water such as agricultural products (e.g., coffee, cocoa, rice etc.), can be at risk considering that the production of many commodities is potentially sensitive to local hydrological extremes at their production locations [4].

The European Union (EU) currently meets some of its water needs by importing virtual water in the form of goods and services from other countries and regions. Previous studies have shown that this external component accounted for approximately $40 \%$ of the Europe's water footprint for the period 1996-2005 [5]. Such reliance on external water resources is a tool for countries to increase their water security and meet increased demand of the economy when local resources are not sufficient. Reliance on food, energy and goods, which require water in their production processes from non-EU regions that are themselves vulnerable to hydrological extremes and climate change, may impose water-related risks to different economic sectors in the EU. For example, the Intergovernmental Panel on Climate Change's 5th Assessment Report [6] suggests that the Mediterranean Basin, Southern Africa, the western USA and southern and eastern Australia will suffer a decrease in water resources, increase in droughts with a consequential reduction in production. This indicates that the structure of production within the EU, and its imports, may need to be adjusted to respond to hydrological extremes that affect the availability of water resources around the world. Changes in the locality of production may have a number of subsequent environmental and social effects, such as increased competition for water, degradation in water quality etc. [1] both in Europe and around the world.

Several authors have previously addressed water use in the production of traded commodities in the context of "virtual water trade" [7-11] and "water footprints" [1,2,11,12]. Virtual water trade, introduced by Allen [13], was formulated to address "water resource management". It aimed to show that water deficit regions, such as the Middle East, can address food production shortages by importing water intensive food products from water rich regions. In this regard, virtual water trade is another way in which countries manager their water and food security risks. The aim of water footprint studies has been to understand the remote impacts of any production and consumption activity by assessing their contribution to water scarcity and sustainability in the producing regions from economic, social and environmental perspectives. None of the existing virtual water/water footprint studies assesses risks or vulnerabilities associated with imports, except a study done by [14] for the UK. Although the title implies risks, it only looks at water scarcity hotspots from water footprint of consumption perspective and addressed only blue water virtual water imports.

The objective of this study is to address the dependency of the EU's economy upon external water resources and assesses its related vulnerabilities to hydrological extremes (current drought and water scarcity) that are occurring outside its borders. To map the current dependencies of the $28 \mathrm{EU}$ member states (EU28), we established the virtual water imports by the EU per economic sector (agriculture, industry and domestic water use) for the period 2006-2013, disaggregating by its green and blue components. Virtual water import (green, blue) by the EU is the volume of water used in the production locations (soil moisture, irrigation) to manufacture the goods and services that are imported by the EU. This analysis enables the water dependencies of the EU's economy on water resources outside its borders to be mapped i.e., the volumes of water consumed in other parts of the world to produce the goods imported into the EU. It also makes it possible to identify which imported products are key to the EU, and where they are produced. Having mapped the key products and their origin, the prevalence of water scarcity and drought in the producing regions is elaborated in order to understand the vulnerability levels related to the production of key imported products. We did vulnerability assessment only for the import of agricultural products. This is the first publication in 
literature, in our knowledge, using virtual water trade analysis framework to assess remote (outside its borders) vulnerabilities of a geographic region to hydrological extremes. Furthermore, this is the first study assessing risks related to green water use by comparing green virtual water imports with drought severity in production locations.

\section{Method and Data}

Firstly, this study focuses on analyzing the virtual water imports by the EU28 countries. Secondly, it identifies the key products and regions upon which the EU economy depends and assesses their vulnerability to water scarcity and drought. The study covers the period 2006-2013 for the EU28 countries (Figure 1).

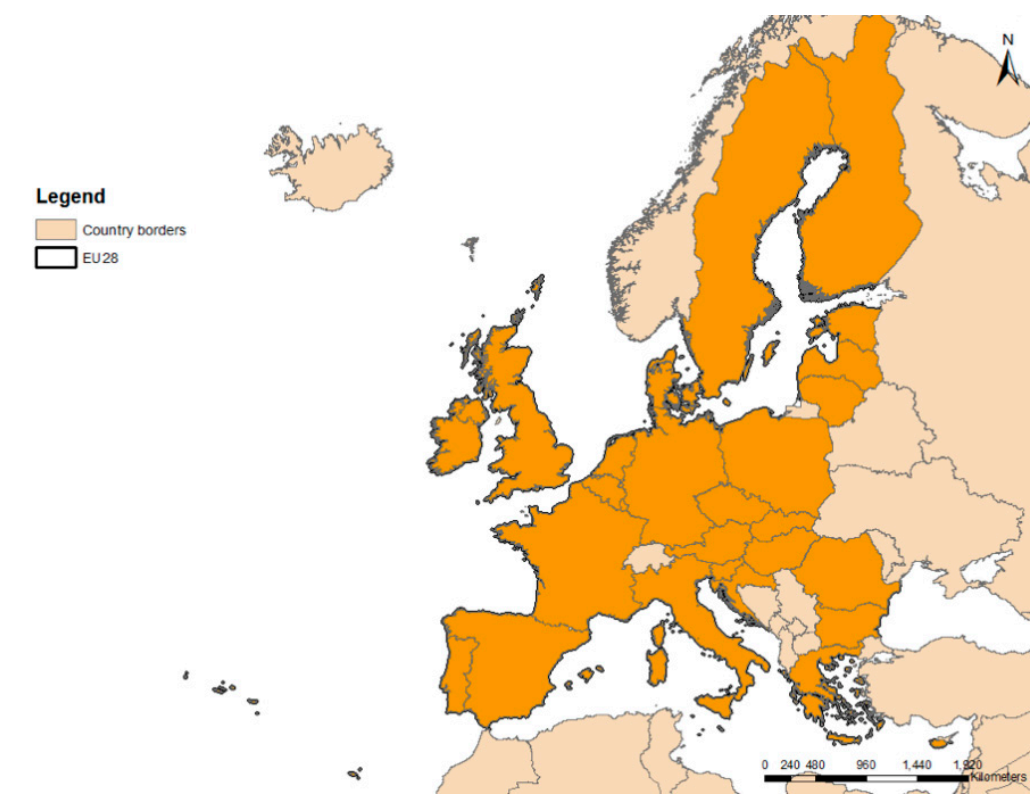

Figure 1. Map of EU28 territories considered in the study.

\subsection{Virtual Water Import by the EU}

The virtual water import by the EU, $V W I_{e u, p y}$, related to product $p$, was calculated equal to the sum of virtual water import by individual EU28 countries from all the countries outside the EU region, non.eu, in year $y$, expressed as:

$$
V W I_{e u, p, y}=\sum_{c=1}^{e u 28}\left(\sum_{e=1}^{\text {non.eu }} T_{p, y, e} \times W F_{e, p, y}\right)
$$

where $T_{c, p, y, e}$ is the physical quantity of the product imported (ton/year), or monetary value (US\$/year) of the imported product (in the case of industrial products) by the EU28 from country $e$ in year $y$; and $W F_{e, p, y}$ is the water footprint $\left(\mathrm{m}^{3} /\right.$ ton or $\left.\mathrm{m}^{3} / \mathrm{US} \$\right)$ of the imported products in the exporting country $e$ in year $y$. The international trade data for the period 2006-2013 was obtained from the ITC trade database $[15,16]$.

The water footprint of a product refers the volume of water consumed to produce the product and has three components [2,11,17]:

- Green water footprint is water from precipitation that is stored in the root zone of the soil and evaporated, transpired or incorporated by plants. It is particularly relevant for agricultural, horticultural and forestry products;

- Blue water footprint is water that has been sourced from surface or groundwater resources and is either evaporated, incorporated into a product or taken from one source and returned to a 
different source, or returned at a different time. Irrigated agriculture, industry and domestic water use can each have a blue water footprint. It shows consumptive use of water;

- Grey water footprint is an indicator for pollution and is defined as the volume of freshwater that is required to assimilate the load of pollutants to meet existing ambient water quality standards.

The virtual water import per nation was calculated for 860 crop products that were traded internationally during the period 2006-2013. The virtual water import per nation related to the import of livestock products was calculated for 126 livestock products that were traded internationally during the period 2006-2013. The virtual water import per nation related to the import of industrial products was calculated for 23 major industrial product categories, following the list of products used by Mekonnen and Hoekstra [18] for the period 2006-2013. In this study we've not included the grey water footprint as water pollution level data for key pollutants from agriculture production per geographical regions are limited and only available for nitrogen and phosphorus from fertilizers use in agriculture.

The import of virtual water by EU28 countries was calculated as external to the EU. Hence, the internal EU trade flows were not included in the total virtual water import estimation. The calculation was made for green and blue water footprints separately for each crop, livestock and industrial product.

\subsection{Water Footprint of a Product}

\subsubsection{Water Footprints of Primary Crops}

The water footprints of the primary crops were calculated by multiplying the average water footprints for crops based on the period 1996-2005 [18], with a specific scaling factor per crop.

$$
W F_{c r, c, y}=W F_{c r, c, a v g 1995-2005} \times f_{s . c r, c, y}
$$

where $W F_{c r, c, y}\left(\mathrm{~m}^{3} /\right.$ ton $)$ is the water footprint of crop $c r$, in country $c$, in year $y$; $W F_{c r, c, a v g 1995-2005}\left(\mathrm{~m}^{3} /\right.$ ton) is the average annual water footprint of crop $c r$, in country $c$ for the period 1996-2005 (taken from the study by Mekonnen and Hoekstra, 2010b); and $f_{s, c r, c, y}$ is the scaling factor for crop $c r$ in year $y$ in country $c$.

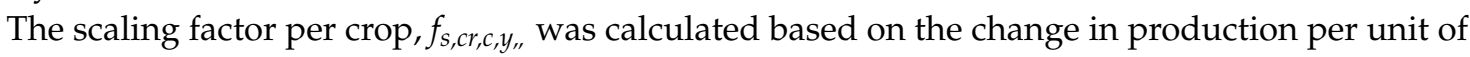
land per crop per country for the current study period, compared to the production in the period used in the previous study by [18].

$$
f_{s . c, e, y}=\frac{\text { Yield }_{c r, c, a v g 1996-2005}}{\text { Yield }_{c r, c, y}}
$$

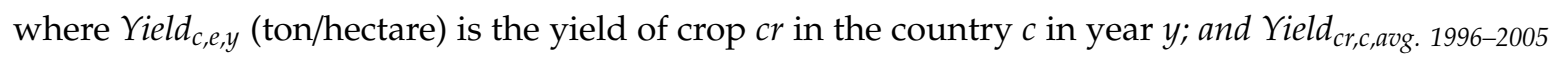
(ton/hectare) is the average yield of crop $c r$ in the country $c$ averaged over the period 1996-2005. The crop yields were taken from FAO [19]. The water footprints of crops were calculated as the green and blue water footprints of 146 primary crops separately, per country per year.

\subsubsection{Water Footprint of Live Animals}

The methodology to calculate the water footprint of live animals is based on [20] and distinguishes between the green, blue and grey water footprint components. The water footprint of live animals is composed of three parts: The water footprint of drinking; the water footprint for servicing and feed preparation; and the water footprint of feed consumed by animals. The water footprint of a live animal related to feed consumption is an indirect part, whereas the first two are direct components (drinking and servicing) of the water footprint of livestock production. It was calculated for three animal production systems (grazing, mixed and industrial), for five species of animal (cattle, swine, sheep, goats and chickens), for livestock products, such as meat and leather etc., and for two animal types; dairy cow (milk and related products) and laying hens (eggs). 
As a first step, the water footprint of a live animal in year $y$ per country $c$ was calculated.

$$
\begin{aligned}
{\text { WF } \text { animal }_{c, y, s, t}=} & P S_{c, y, s, t} \times\left(\text { WFfeed }_{c, y, s, t}+\right.\text { WFdrinking } \\
& \left.+ \text { WFservice }_{c, y, s, t, t}\right) \times \frac{A L W_{t}}{A L S_{t}}
\end{aligned}
$$

where WF animal $c, y, s, t$ is the water footprint of animal $t\left(\mathrm{~m}^{3} /\right.$ animal/year) in country $c$, year $y$; and WFfeed $_{c, y, s, t}$ is the water footprint related to feed consumption $\left(\mathrm{m}^{3}\right.$ per ton of live animal weight). WFdrinking $c, y s, t$ is the drinking water consumed by the animal $\left(\mathrm{m}^{3}\right.$ per ton of live animal weight); WFservice $_{c, y, s, t}$ is the water consumed in the animal husbandry activities $\left(\mathrm{m}^{3}\right.$ per ton of live animal weight); and $P S_{c, y, s, t}$ is the relative share of the production system $s$ (grazing, mixed or industrial) per country $c$ and animal type $t$. The relative share of animal production from different production systems per country was calculated using data on the water footprint of livestock production per system obtained from Mekonnen and Hoekstra [20], and was considered constant for the study period. The values of WFdrinking $g_{s, t}$ and WFservice $_{s, t}$ per animal type and production system were obtained from Mekonnen and Hoekstra [20]. $A L W_{t}$ is the animal live weight (mass/animal) per animal type $t$, and $A L S_{t}$ is the productive animal life span (years) per animal type $t$.

The major component in livestock's water footprint is related to feed consumption which was calculated as the summation of the water footprint of feed concentrate (WFconc.) and fodder (WFfodder):

$$
W_{\text {Wfeed }}, y, s, t=\left(\text { WFconc }_{c, y, s, t}+W F \text { fodder }_{c, y, s, t}\right) \times C W_{t}
$$

in which $C W_{t}$ is the weight of the livestock output expressed as the fraction of live weight (weight of livestock output/weight of live animal) per animal type $t$.

The water footprint of feed concentrate WFconc $c_{c, y, s, t}$, expressed in $\mathrm{m}^{3}$ per ton of live animal or total output, in country $c$, year $y$, production system $s$ and animal type $t$, was calculated as:

$$
\begin{aligned}
& W_{\text {Fonc }} c_{c, y, s, t}=\sum_{c r=1}^{C}\left(\text { Wconc }_{c, y, s, t, c r} \times W F \operatorname{conc} c_{c, y, c r}^{*}\right) \\
& =\sum_{c r=1}^{C}\left(\operatorname{fronc}_{c, s, t} \times \frac{1}{A F C E_{s, t}} \times W F \operatorname{Wonc}_{c, y, c r}^{*}\right)
\end{aligned}
$$

in which WFconc $c_{c, y, s, t}$ is the water footprint of feed concentrate $\left(\mathrm{m}^{3}\right.$ per ton of animal output) in country $c$, year $y$, production system $s$ and animal type $t ; A F C E_{s, t}$ is the animal feed conversion efficiency (mass live animal output/mass of feed) in production system $s$ and animal type $t ; f_{c o n c} c_{c, s, t}$ is the fraction of concentrate in feed (mass of concentrate/mass of feed) in country c, for year y and animal type $t$; $W_{c o n c} c, y, s, t, c r$ is the weight of concentrate per feed crop (ton) in country $c$, for year $y$, crop $c r$, production system $s$ and animal type $t$; and $W F c o n c_{c, y, c r}^{*}$ is the water footprint of the feed crop $c r$ included in the feed concentrate $\left(\mathrm{m}^{3}\right.$ per ton of feed). The feed conversion efficiencies were obtained from Mekonnen and Hoekstra [20].

One of the main factors determining livestock's water footprint is the feed composition (weight and type of feed crop), which is adapted from Mekonnen and Hoekstra [20] and Wheeler et al. [21] It includes three basic categories of feed concentrate products: Cereals; oil-meals; and other concentrates. The composition of specific crops and crop products in the feed concentrate per country and year is based on data from FAO's Food Balance Sheets [22].

The water footprint for each crop product, both in importing and exporting countries, was weighed using the share of import and national production (ton per year) to the total quantity of crop used as feed in the country (sum of crop imports and national production of crops used as feed expressed in 
ton per year). The share of national production and import per crop, country and year were obtained from FAO's Food Balance Sheets [22].

$$
\begin{aligned}
\text { WFonc }_{c, y, c r}^{*}= & \left(\sum_{e=1}^{E}\left(\frac{\text { Import }_{c, y, e, c r}}{\left(\sum_{e=1}^{E} \text { Import }_{c, y, c, c r}\right)+\text { Production }_{c, y, c r}} \times W F_{e, y, c r}\right)\right) \\
& +\left(\frac{\text { Production }_{c, y, c r}}{\left(\sum_{e=1}^{E} \text { Import }_{c, y, e, c r}\right)+\text { Production }_{c, y, c r}} \times W F_{c, y, c r}\right)
\end{aligned}
$$

in which Import $t_{c, y, e, c r}$ refers to the quantity of import (ton/year) of the specific feed crop $c r$ per importing country $c$ from country $e$ in year $y ;$ Production $_{c, y, c r}$ refers to the national production of the specific crop $c r$ (ton/year) per importing country $c$ in year $y ; W F_{c, y, c r}$ is the water footprint $\left(\mathrm{m}^{3} /\right.$ ton) per crop in the importing country $c$, year $y$ and crop $c r$; and $W F_{e, y, c r}$ is the water footprint $\left(\mathrm{m}^{3} /\right.$ ton) per crop $c r$ in the exporting country $e$ (where $E$ refers to the total number of exporting nations of that particular crop) in year $y$.

The water footprint of fodder WF fodder $_{c, y, s, t}$ is calculated as:

$$
W_{F f o d d e r}, y, s, t=\left(A F C E_{s, t} \times\left(1-f \operatorname{conc}_{c, s, t}\right) \times W F \text { fodder }_{c, y}^{*}\right) \times C W_{t}
$$

in which $\operatorname{fconc}_{c, s, t}$ is the fraction of concentrate in feed (mass of concentrate/mass of feed); the factor $\left(1-F_{c o n c_{c, s, t}}\right)$ indicates the fraction of fodder in the feed that is consumed by the animal; and $W F f_{0} d d e r_{c, y}^{*}$ is the water footprint of fodder products ( $\mathrm{m}^{3}$ per ton of product); and $C W_{t}$ is the weight of the livestock output expressed as the fraction of live weight (weight of livestock output/weight of live animal) per animal type $t$.

Fodder can consist of several types of feed crops with low nutrient density and high fiber content, such as pasture, roughage, or crop residues and by-products. In this study, all the fodder consumed by ruminant animals is assumed to be composed of pasture. The water footprint of pasture was obtained from Mekonnen and Hoekstra's [20] world average values. For monogastric animals (poultry and swine), fodder crops are a mixture of several crops, known as roughage. The water footprint of roughage was calculated by considering the average yield of the crops included in the roughage per year and country.

\subsubsection{Water Footprints of Processed Crop and Livestock Products}

The water footprints of primary crops and live animals were used to calculate the water footprints of derived crop and livestock products, using the product fraction and the value fraction [2]:

$$
\text { WFcropproduct }_{y, c}=\text { WFcrop }_{y, c, c r} \times \frac{f v_{c r}}{f p_{c r}}
$$

where WFcroproduct $t_{y, c, t}$ is the water footprint of the crop products originating from the primary crop $c r$, year $y$, country $c$; and $f p_{, c r}$ is the product fraction of the crop $c r$ taken from Mekonnen and Hoekstra [18]. The value fraction for crop products, $f v_{c r}$, was calculated for the more recent period, based on the average total internationally traded monetary value of the products for the period 2006-2013, using trade statics from ITC $[15,16]$.

$$
f v_{p}=\frac{\text { price }_{p} \times w_{p}}{\sum_{p=1}^{P}\left(\text { price }_{p} \times w_{p}\right)}
$$

in which price $_{p}$ is the global average price of product $p$ in the period (monetary unit/mass) and $w_{p}$ is the weight of the product $p$, obtained from Mekonnen and Hoekstra [18]. The denominator is sum of the $P$ output products $(p=1$ to $P$ ) that originate from the input product.

The water footprints of the 107 processed livestock products used in this study were calculated using the product fraction and value fraction of these products, derived from corresponding animal types. 
Product and value fractions for animal products were obtained from Mekonnen and Hoekstra [20].

$$
\text { WFlvstPrd }_{y, c, t}=\text { WFanimal }_{y, c, t} \times \frac{f v_{p}}{f_{p_{p}}}
$$

where WFlvstPrd $d_{y, c, t}$ is the water footprint per livestock product in year $y$, country $c$ and animal type $t$; WFanimal $_{y, c, t}$ is the water footprint per live animal $\left(\mathrm{m}^{3} / \mathrm{animal} / \mathrm{year}\right)$ in year $y$, country $c$ and animal type $t ; f v_{p}$ is the value fraction for livestock product $p$; and $f_{p_{p}}$ is the product fraction for livestock product $p$.

\subsubsection{Key Imported Products}

Key imported products were selected based on their ranking relative to the main virtual water flows into the EU. Crops were ranked considering the annual average virtual water import volumes to the EU from the largest to the smallest, separately for the green and blue water footprint components. In the case of the green water footprint, crops with green virtual water import volumes larger than $2 \%$ of the total green virtual water import related to crops were identified as the key imported products. In the case of the blue water footprint, crops with blue virtual water import volumes larger than 3.5\% of the total blue crop virtual water import to the EU were selected as the key imported products.

\subsubsection{Vulnerability Assessment}

The vulnerability of virtual water imports to the EU was assessed by elaborating drought severity and water scarcity at the producing locations of the key imported products for green and blue virtual water imports, respectively.

To assess the vulnerability level that occurs in the producing regions of the key products selected, green virtual water import maps of the key products were overlaid with drought risk maps from Gassert et al. [23]. This work developed a $1^{\circ}$ by $1^{\circ}$ gridded data set of the mean severity of drought events from 1901 to 2008, by generating a monthly soil moisture hydrograph and defining drought events as periods of time when monthly soil moisture falls below the 20th percentile. Severity was then evaluated as the multiplication of length (in months) and spatial spread (the number of places in an area) of drought events. Gassert et al. [23] averaged the results per river basin and normalized them to define five severity levels: Low; low to medium; medium to high; high; and extremely high. Low drought severity means that drought events are either short in time or affect a small spatial spread, or both. High drought severity implies longer, more frequent and wider-spread drought events. Four levels of vulnerability were defined according to the drought severity level: Low (for low, and low to medium drought severity); moderate (medium to high drought severity); high (high drought severity); and very high (extremely high drought severity) (Table 1).

Table 1. Vulnerability levels and corresponding drought severity index and blue water scarcity category.

\begin{tabular}{ccc}
\hline & $\begin{array}{c}\text { Normalised Drought Severity Index } \\
\text { (Normalised Mean Soil Drought Severity) }\end{array}$ & Blue Water Scarcity Category \\
\hline Low & $<30$ & $<1.0$ \\
Moderate & $30-40$ & $1.0-1.5$ \\
High & $40-50$ & $1.5-2.0$ \\
Very high & $>50$ & 2.0 \\
\hline
\end{tabular}

The vulnerability of the selected key products for blue virtual water import was assessed by elaborating water scarcity levels in the producing locations. Blue virtual water import maps of the key products were compared with average annual water scarcity map from Mekonnen and Hoekstra [14]. The authors defined water scarcity as the ratio of the total blue water footprint divided by blue water availability. They calculated the blue water availability as the runoff generated, minus environmental 
flow requirements. The classified water scarcity (WS) is defined as low if the blue water footprint does not exceed blue water availability (WS $<1.0$ ); in this case, environmental flow requirements are met. Water scarcity is said to be moderate if it is in the range $1.0<\mathrm{WS}<1.5$; significant if it is in the range $1.5<$ WS $<2.0$; and severe if WS $>2.0$. Four vulnerability levels were defined for the blue virtual water imports corresponding to water scarcity levels: Low (low water scarcity); moderate (moderate water scarcity); high (significant water scarcity); and very high (severe water scarcity).

\section{Dependencies of the EU on Water Resources Outside Its Borders}

We define dependencies of the EU on water resources outside its borders in terms of virtual water imports to the EU, which are determined by two elements: Quantity of products (in physical mass) imported, and the water footprint of the product $\left(\mathrm{m}^{3}\right.$ per unit of mass of product). The total virtual water import to the EU for the period 2006-2013 was $333 \mathrm{~km}^{3} /$ year. Crop products account for the largest share of the virtual water import to the EU (72\%), followed by industrial products (22\%) and animal products $(6 \%)$ (Table 2$)$.

Table 2. Virtual water import to the EU ( $\mathrm{km}^{3} /$ year) by major product groups, average for 2006-2013.

\begin{tabular}{ccc|ccc|cc}
\hline & Crop Products & \multicolumn{3}{c|}{ Animal Products } & \multicolumn{2}{c}{ Industrial Products } \\
\hline Green & Blue & Grey & Green & Blue & Grey & Blue & Grey \\
223 & 9 & 9 & 19 & 0.5 & 0.3 & 4 & 68 \\
\hline
\end{tabular}

The green water footprint of imported products was $243 \mathrm{~km}^{3} / y e a r$, which is $73 \%$ of the EU's total virtual water import. Soybean products account for $27 \%$ of the total green virtual water import. Cocoa products $(19 \%)$, coffee products $(14 \%)$, palm oil products $(9 \%)$ and animal products $(8 \%)$ also have a significant share in the EU's green virtual water import (Figure 2).

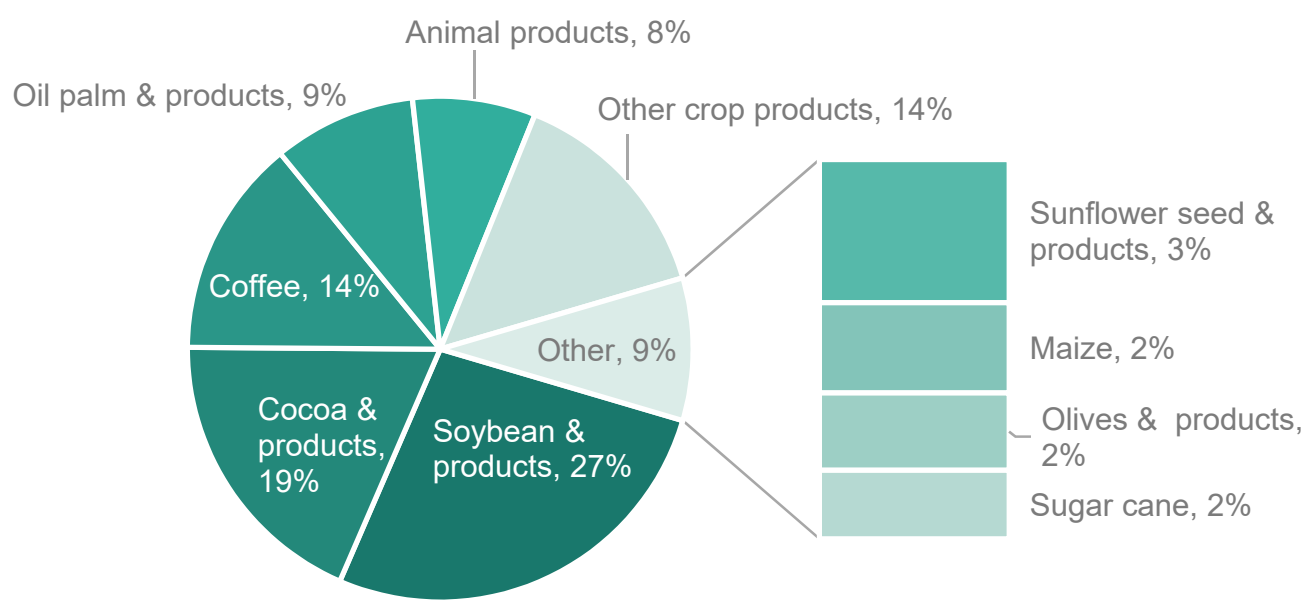

Figure 2. Green virtual water import to the EU by product group, average for 2006-2013.

Agricultural products account for largest $67 \%$ of the blue water footprint of imported products: Rice $(9 \%)$, sugarcane $(7 \%)$, cotton $(7 \%)$, almonds $(4 \%)$, pistachios $(3 \%)$, animal products $(3 \%)$, grapes and wine (3\%), and soybean products (3\%) (Figure 3$)$. 


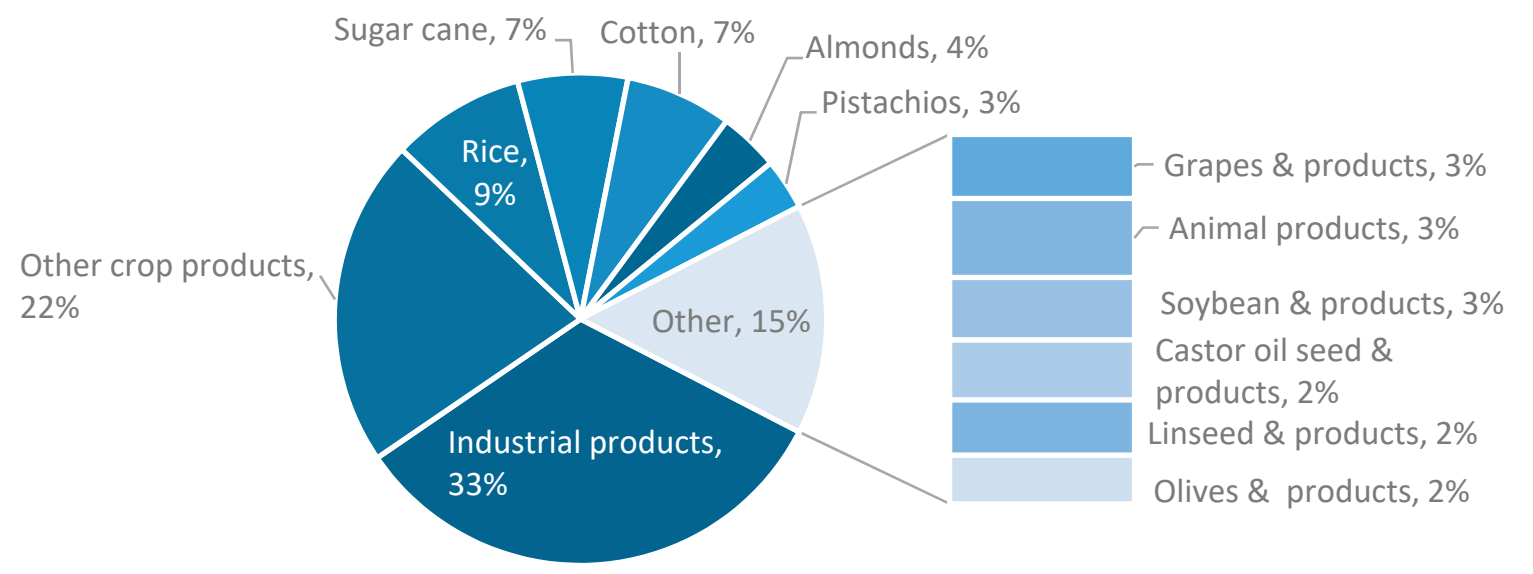

Figure 3. Blue virtual water import to the EU by product group, average for 2006-2013.

More than $90 \%$ of total green virtual water import to the EU are from Brazil, Argentina, Ivory Coast, Ghana, Indonesia and Malaysia and is related to the import of crop products (Figure 4). More than half of the total virtual water import from the USA is from crop products, with the largest share being the green water footprint (52\%) followed by the grey $(35 \%)$ and blue $(15 \%)$ water footprint components.

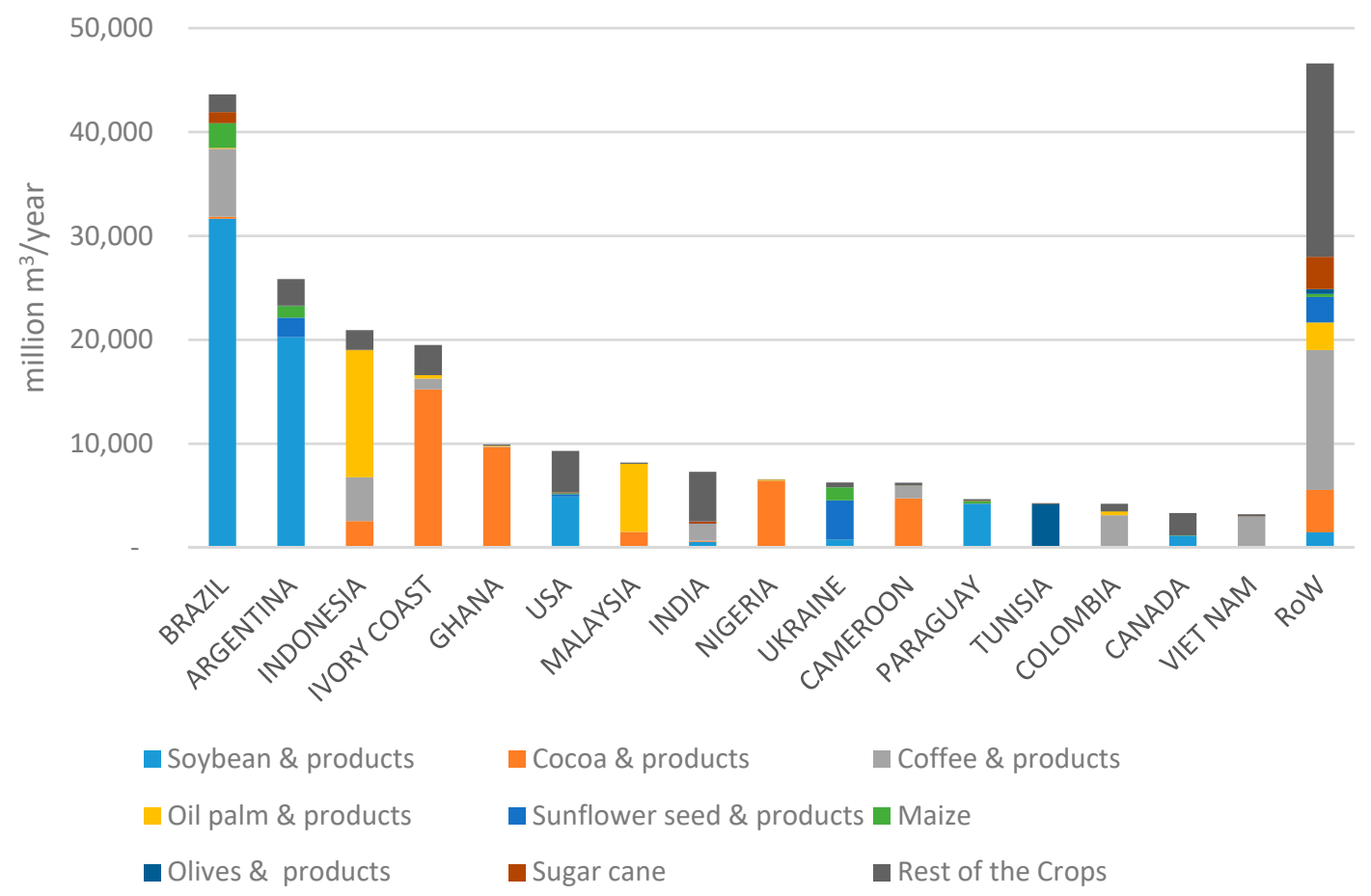

Figure 4. Green virtual water imports to the EU per country, per crop product and product groups (million $\mathrm{m}^{3} /$ year). RoW; Rest of the World.

The USA (17\%), India (9\%), Pakistan (8\%), Turkey (6\%), Egypt (6\%), Iran (4\%) and South Africa $(4 \%)$ are the largest blue virtual water exporters to the EU related to crop products, accounting for $54 \%$ of the blue virtual water import by the EU (Figure 5). The crop products with the largest blue virtual water exports from these countries to the EU are: Almonds (33\% of the EU's blue virtual water import from the USA); rice ( $24 \%$ and $21 \%$ of EU's blue virtual water import from Egypt and India respectively); cotton products (33\% of EU's blue virtual water import from Turkey); pistachios ( $88 \%$ of EU's blue virtual water import from Iran); and grapes (24\% of EU's blue virtual water import from South Africa) (Figure 5). 


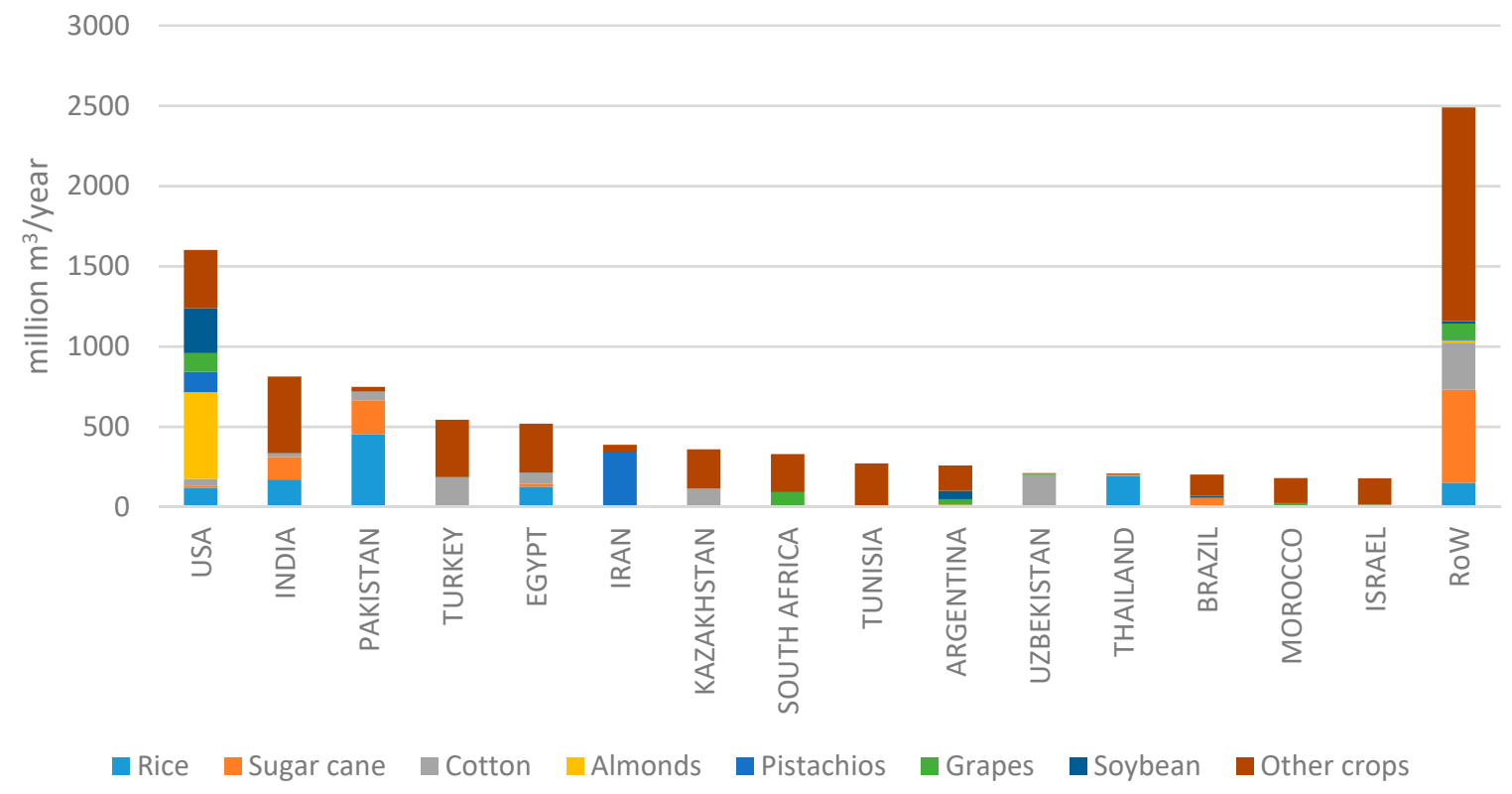

Figure 5. Blue virtual water imports to the EU per country, per crop product group (million $\mathrm{m}^{3} /$ year).

\section{Key Imported Products and Their Production Locations}

The analysis made identified the key imported products that contribute significantly to the EU's virtual water imports. As their virtual water import volumes are large, the dependency of the EU economy on water resources in the regions that produce these commodities is higher. Thus, the vulnerability of these products to drought and climate change in their production locations may directly affect supplies that the EU economy depends upon. Industrial and livestock products are not included on the list of key imported products, because the exact locations in which each industrial commodity and livestock product is produced are either unknown, or are only known at the country level, which makes it difficult to conduct an accurate vulnerability assessment.

The key imported products were identified separately for the green and blue virtual imports in order to assess vulnerabilities due to drought (green component) and water scarcity (blue component). The grey virtual water imports were not included in the key product identification because they are not directly related to blue water availability in the producing regions, and changes in blue water availability may, or may not, affect the supply of products to the EU.

Soybean, cocoa, coffee, palm oil, sunflower, maize and olives were selected as key products from the perspective of green virtual water import; they represent around $81 \%$ of the total green virtual water import to the EU. Soybean has the largest green virtual water import volume to the EU, with imports coming from Argentina, Brazil and the USA. Europe relies on soybean imports to meet demand for meat and dairy products. Soybean is little grown in the EU relative to European demand and its cultivation has important economic and political implications. EU demand far exceeds its own internal production, which is only 0.9 million tons per year. Imports reach around 30-35 million tons per year (average for 2006-2013). The deficit in soybean production in the EU poses a significant risk to the EU economy due to the region's need for, and reliance on, imports. The green virtual water imports to the EU related to soybean are presented in the top map of Figure 6.

The largest green virtual water import volumes for cocoa come from the Ivory Coast $(34 \%)$, Ghana (23\%), Nigeria (14\%), Cameroon (11\%) and Indonesia (6\%). The cocoa sector in Europe is fully dependent on imports. The green virtual water imports to the EU related to cocoa are presented in the second to top map of Figure 6. 


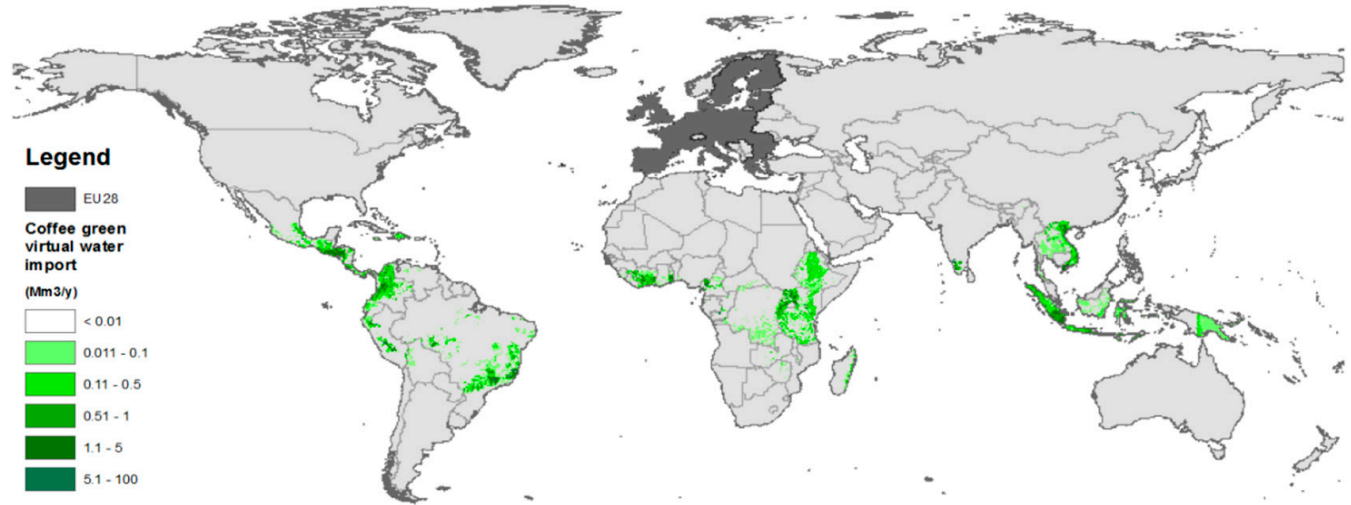

(a)

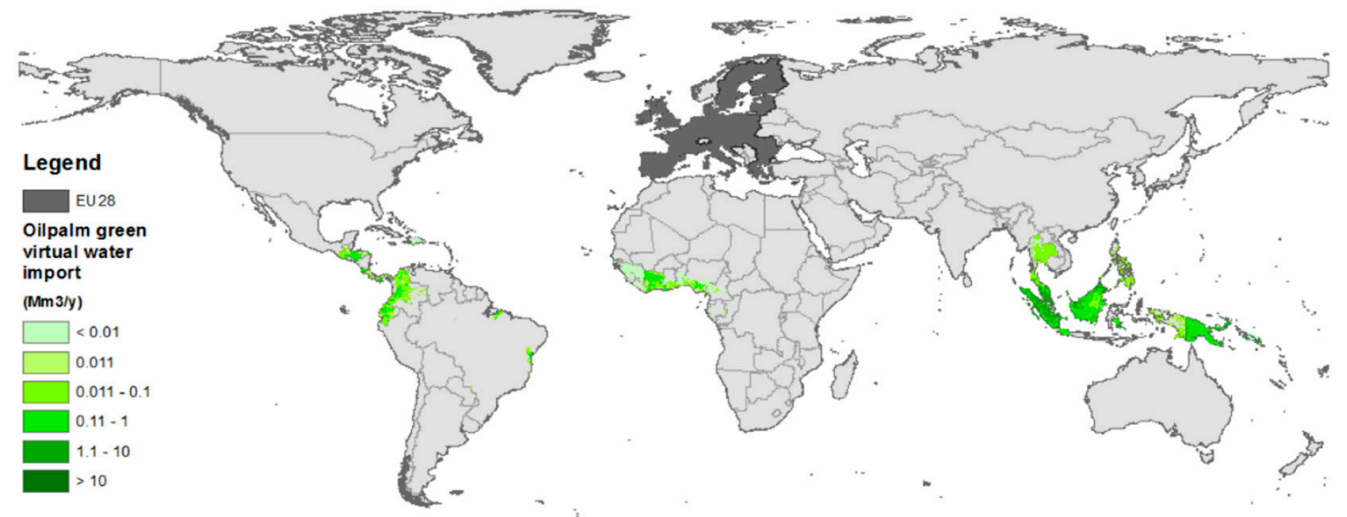

(b)

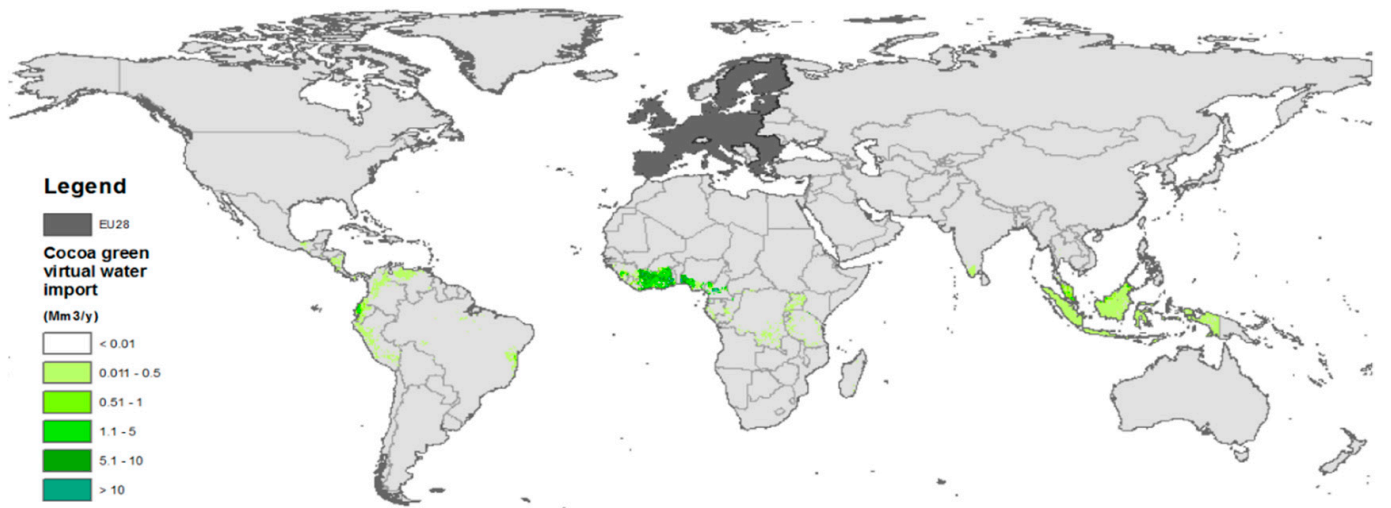

(c)

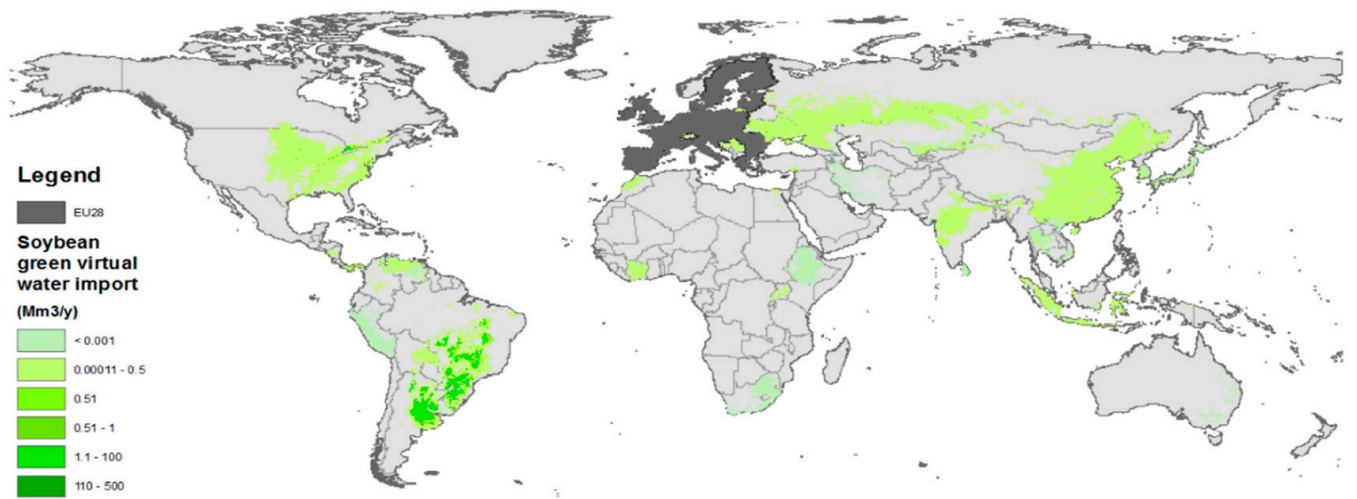

(d)

Figure 6. Green virtual water imports to the EU per grid cell related to coffee (a), oil palm (b), cocoa (c) and soybean (d) (million $\mathrm{m}^{3} /$ year). 
The largest green virtual water imports to the EU related to palm oil products originate from Indonesia (55\%), followed by Malaysia (29\%) and Papua New Guinea (9\%) (Figure 6). Palm oil is used in the production of a wide range of goods and services, from food products, such as crisps and biscuits, and household goods, such as washing powder, to health and beauty products. It is also used as a source of energy. It is estimated that palm oil contributes around $€ 2.7$ billion to the EU's Gross Domestic Product (GDP) [24].

The largest green virtual water imports to the EU related to maize originate from Brazil (43\%), Ukraine (23\%) and Argentina (21\%). A majority of the green virtual water imports related to olives come from Tunisia $(89 \%)$. The green virtual water imports related to sunflower originate from Ukraine $(45 \%)$, Argentina (22\%) and Russia (19\%).

The key products selected from the blue virtual water perspective were rice, sugarcane, cotton, almonds, pistachios, grapes and soybean, which together represent $54 \%$ of the total blue virtual water import to the EU. The largest blue virtual water imports related to rice are from Pakistan $(36 \%)$, Thailand (15\%), India (14\%), Egypt (10\%), the USA $(10 \%)$ and Uruguay $(5 \%)$. The blue virtual water imports to the EU related to rice are presented in the top map of Figure 7. Sugarcane-related blue virtual water imports are mainly from Pakistan $(21 \%)$, India (14\%), Swaziland (12\%), Zimbabwe $(8 \%)$, Zambia $(6 \%)$ and Sudan $(5 \%)$. The blue virtual water imports to the EU related to sugarcane are presented in the bottom map of Figure 7. Overall, the largest contributors to blue virtual water imports related to cotton to the EU are Uzbekistan (20\%), Turkey (18\%), Tajikistan (14\%), Kazakhstan (11\%), Egypt (7\%) and Pakistan (6\%) (Figure 7).

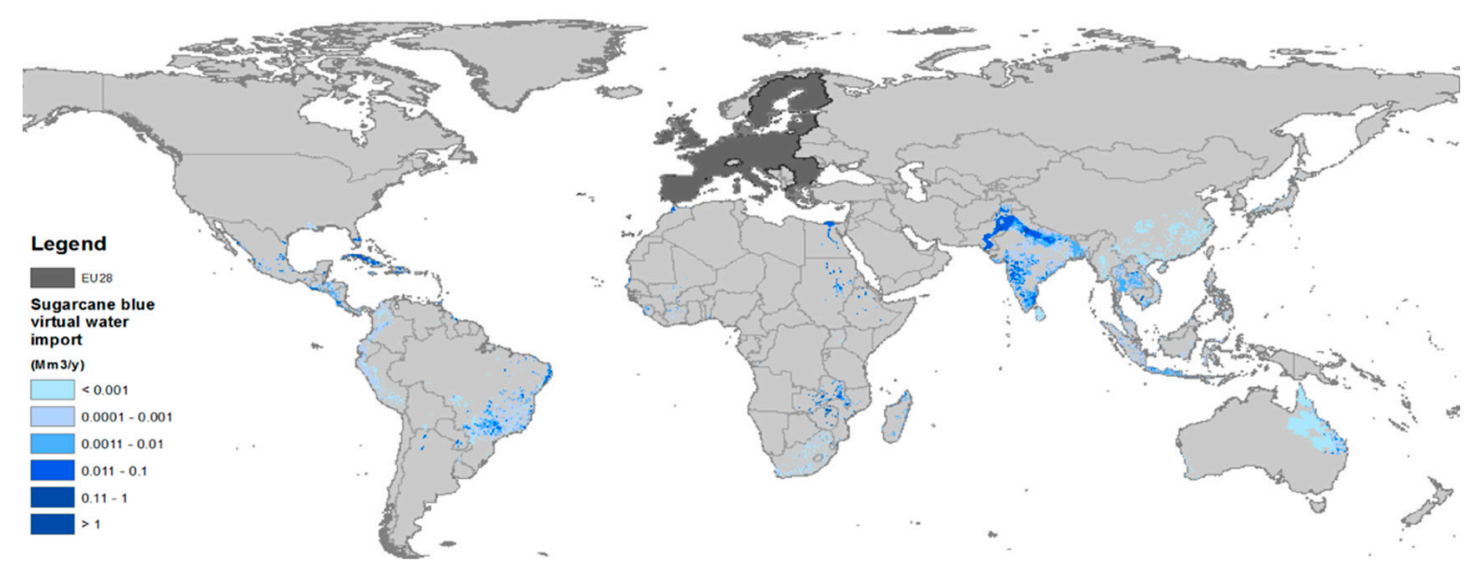

(a)

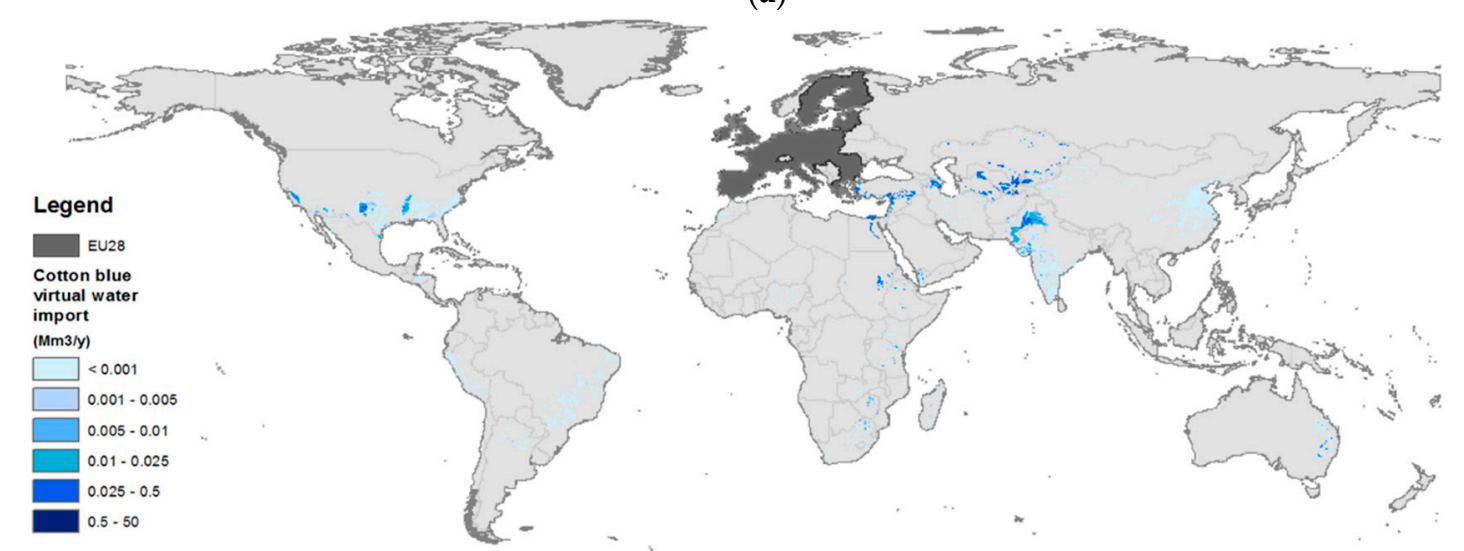

(b)

Figure 7. Cont. 


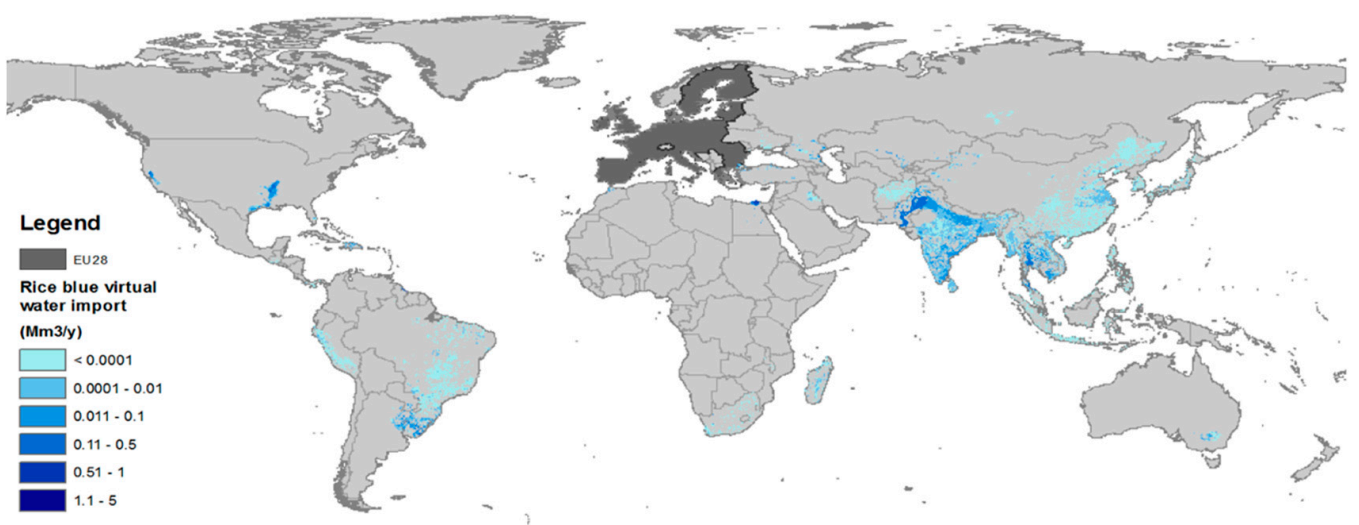

(c)

Figure 7. Blue virtual water imports to the EU per grid cell related to sugarcane (a), cotton (b) and rice (c) (million $\mathrm{m}^{3} /$ year).

\section{Vulnerability Assessment}

\subsection{Vulnerability of Green Virtual Water Imports to the EU}

Around $99.5 \%$ of green virtual water imports to the EU related to soybean come from the locations with a low drought risk, thus the vulnerability level is categorized as "low". The rest $(0.5 \%)$ are categorized as "moderate" (Figure 8). Similar to soybean, the vulnerability level of over $90 \%$ of the green virtual water imports related to oil palm, coffee, cocoa (Figure 8), sunflower and maize are categorized as "low". Only in the case of olives, around $32 \%$ of the green virtual water imports to the EU are sourced from locations with a "moderate" vulnerability level, mainly in Tunisia.

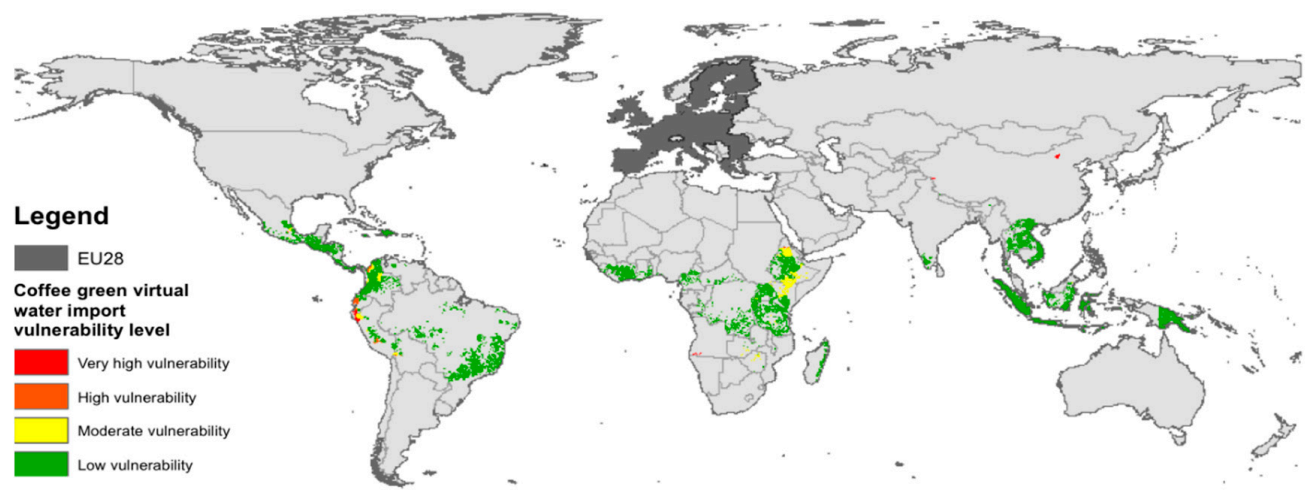

(a)

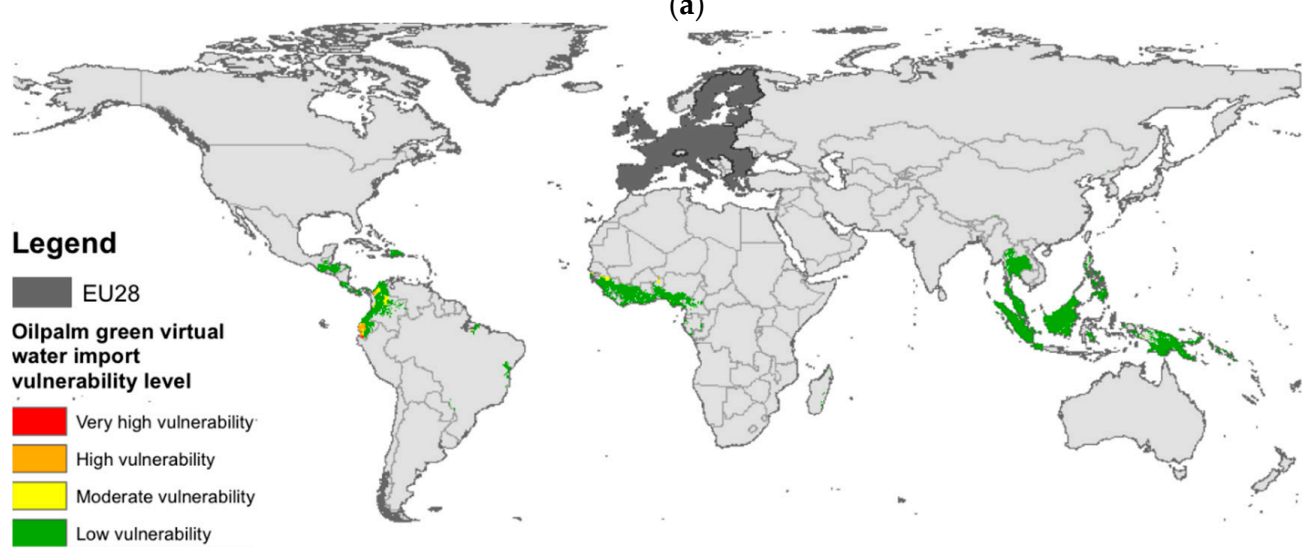

(b)

Figure 8. Cont. 


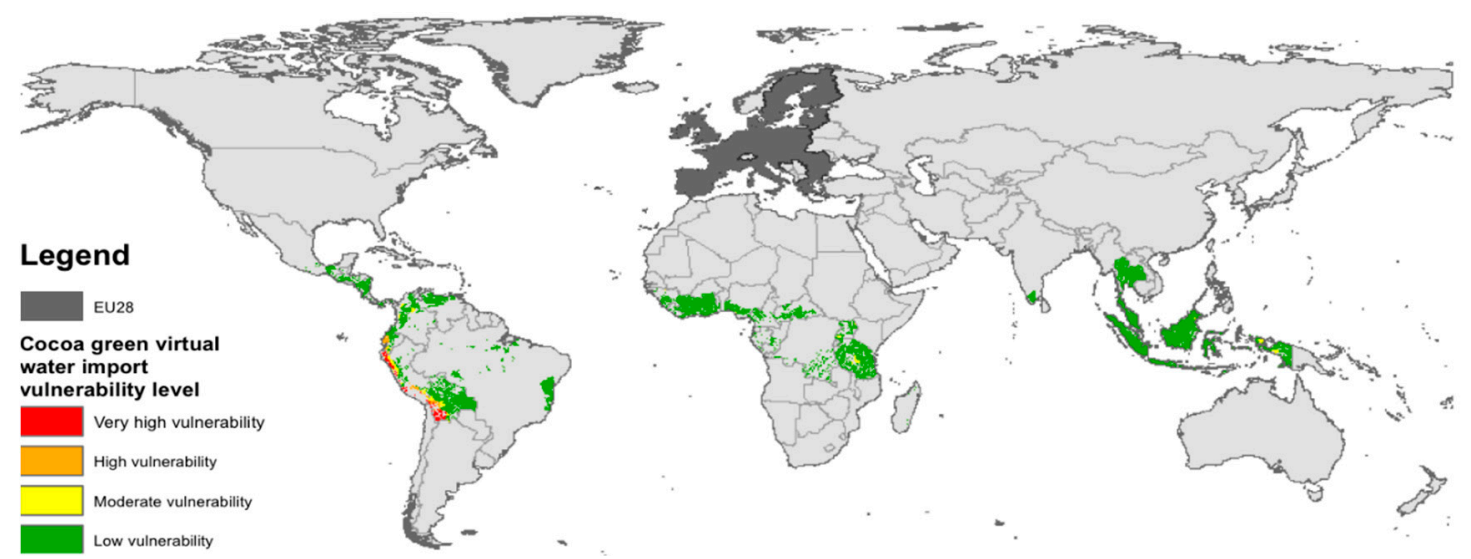

(c)

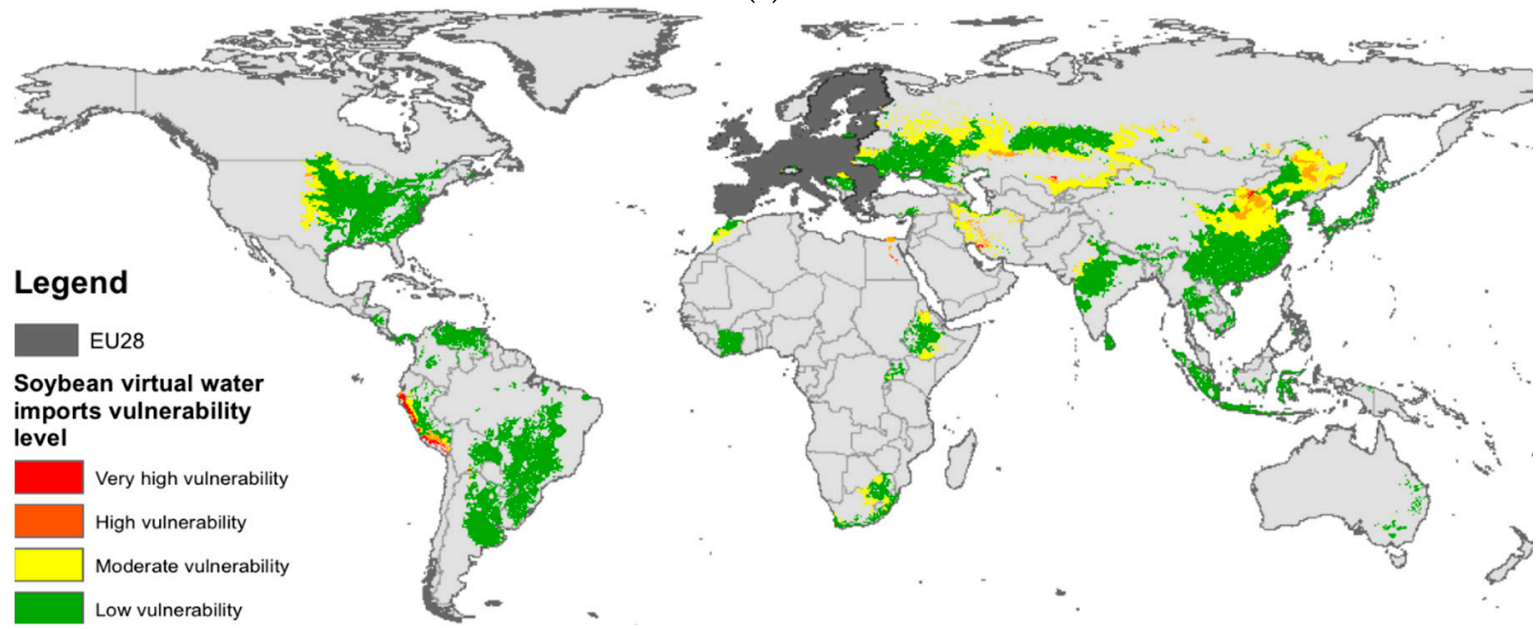

(d)

Figure 8. Vulnerability level for green virtual water imports to the EU related to coffee (a), oil palm (b), cocoa $(\mathbf{c})$ and soybean $(\mathbf{d})$.

\subsection{Vulnerability of Blue Virtual Water Imports to the EU}

A majority (54\%) of the key crops for blue virtual water import (rice, sugarcane, cotton, almonds, pistachios, grapes and soybean) are sourced from areas under significant or severe water scarcity. This means that the majority of crop-related blue virtual water imports to the EU are "highly vulnerable". For example, $91 \%$ of the blue virtual water imports for almonds imported to the EU are categorized as "highly vulnerable". Of other key products, $87 \%$ of pistachio imports, $74 \%$ of grape imports, $70 \%$ of rice and cotton imports, $57 \%$ of soybean and $56 \%$ of sugarcane imports are all considered "vulnerable". Maps of the vulnerability levels of blue virtual water imports to the EU related to cotton, rice and sugarcane are presented in Figure 9. 


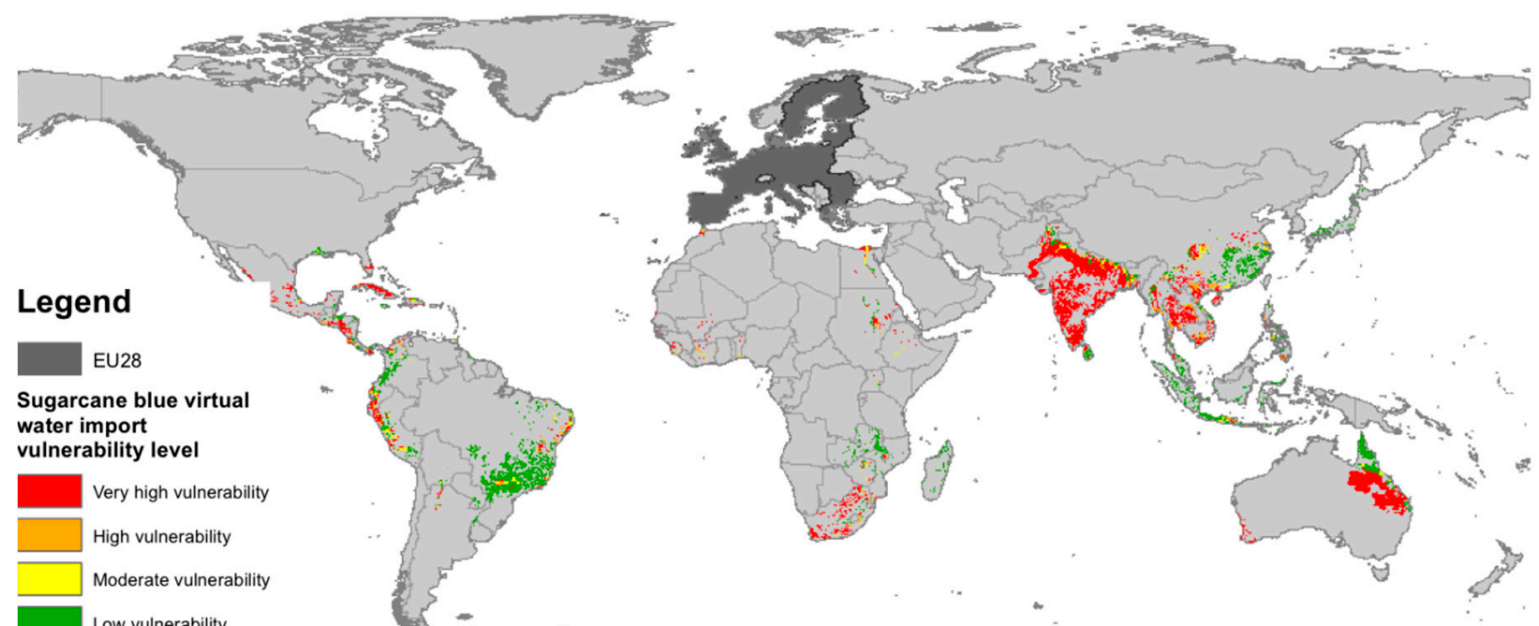

(a)

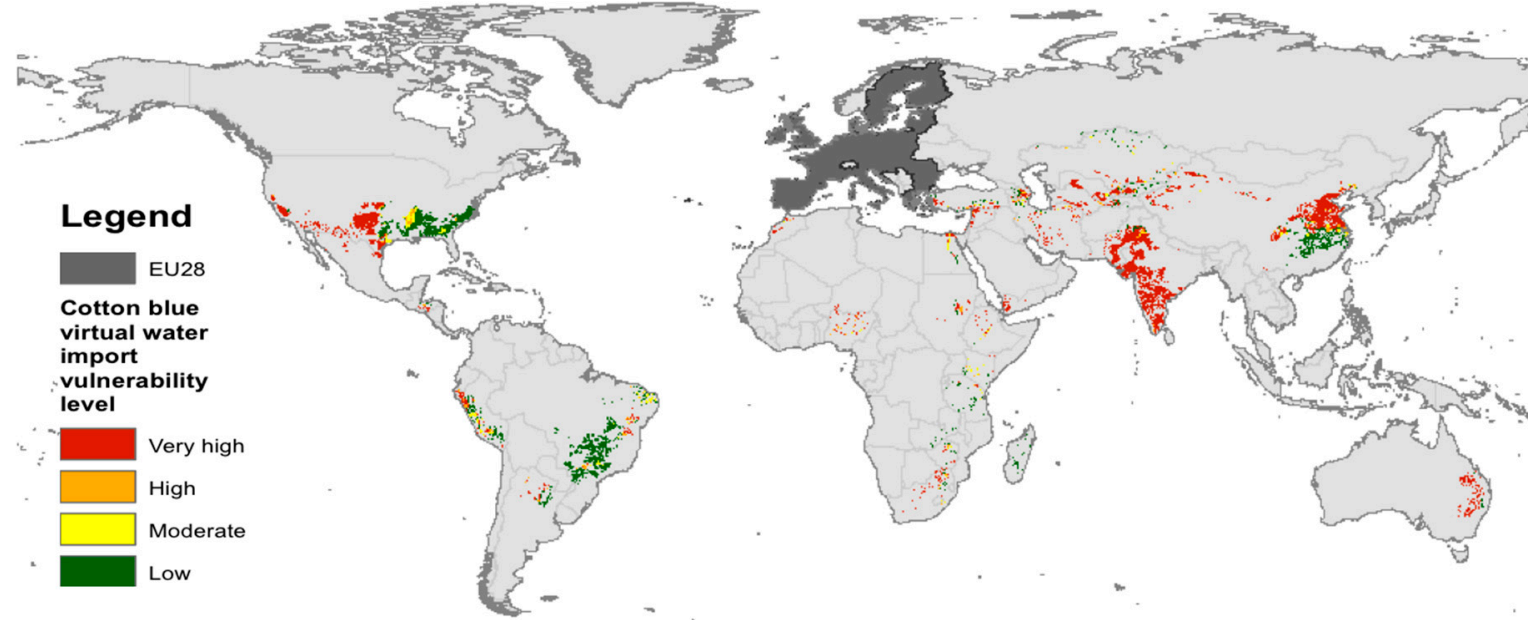

(b)

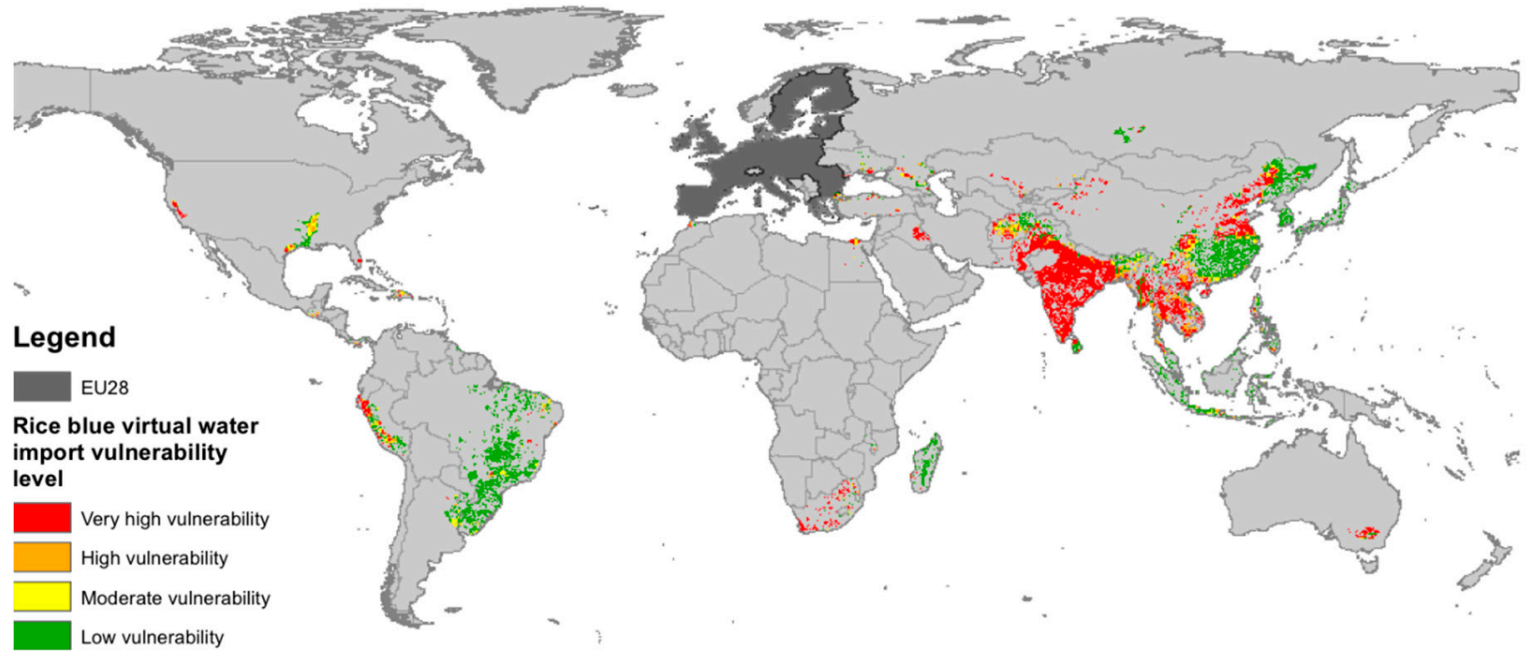

(c)

Figure 9. Vulnerability maps for blue virtual water imports to the EU for sugarcane (a), cotton (b) and rice $(\mathbf{c})$.

\section{Discussion}

The EU (and the member nations) has been seeking solutions, developing policies towards improving resilience of the EU's agriculture to droughts and water scarcity happening inside the 
borders of the EU [25]. This is a logical, straight forward approach because production activities in the EU such as agriculture would immediately feel the impacts of insufficient rainfall and lack of water. The results and analytics presented in our study may move this approach to a new step since we clearly showed vulnerabilities of some sectors in the EU, such as dairy and meat, chocolate (cocoa), coffee production, to hydrological extremes also lie outside the EU's borders, in addition to the inside. A good example for this is soybean with the largest dependency on countries outside the EU in terms of water. The EU relies almost entirely on imports of soybean to meet demand for animal feed for meat and dairy products. Therefore, the deficit in soybean production in the EU poses a significant risk to its economy and especially to the EU meat industry, due to high demand for the product, its high reliance on imports and the vulnerability of the crop to drought and water scarcity in the countries of origin as shown in our study (around 57\% of soybean supply is highly vulnerable to water scarcity in producing regions). EU-wide strategies, such as the Climate Adaptation Strategy and the EU's agricultural trade policy and international development strategies at pan-European and regional level can benefit from the results of our assessment and can address these dependencies on a sectoral basis to mitigate any negative consequences that the EU economy may face. The EU can also consider vulnerabilities in developing bi-lateral relations with its trade partners using the outcomes of our study. Examples of actions that can be explored range from the inclusion of environmental considerations in the trade agreements to strengthening capacitation and governance for drought adaptation or favoring investments towards water security improvement in the exporting countries. Furthermore, this analysis may be used in the coordination and strategic decision-making of external action and international cooperation, in particular towards the EU's intended contribution to meeting the SDG 6.

Virtual water trade and water footprint assessment studies have been focusing on identifying water dependencies but using such information in understanding impacts or for sustainability assessments of the imports from water perspective $[10,26,27]$. We, in this study, demonstrated how to use virtual water trade analysis in vulnerability and risk assessment including its quantification by merging virtual water trade volumes together with level of water scarcity and drought severity in production locations. This way we managed to quantify vulnerability levels of the EU's agricultural imports and identified critical key imported products and their sensitivity level to hydrological extremes. Our paper has answered the questions of how dependent we are to external water resources and how much vulnerable they are to hydrological extremes. Although we only used water scarcity and drought severity, the framework can also be applied to other extreme conditions such a flood, heat stress etc. Furthermore, it can be used to analyze how extreme weather conditions would be altered under climate change and how this would change vulnerability levels of the EU's external water dependency.

Our analysis also showed the relevance of quantifying and addressing water footprints separately by green and blue use components. Drought severity in production locations of the imported crops is directly related to the green water footprint component and water scarcity is with the blue water footprint. Previous studies always looked into blue water footprints and virtual water trade in translating them impact, sustainability or risk assessments. Our results, mapping high dependency of imports to rainfall and its consequent vulnerability to drought, shows the role and importance of green water footprint accounting in risk identification and vulnerability assessment.

In our assessment of vulnerability, we have considered existing trade (2006-2013), blue water scarcity (average 1996-2005) and drought severity conditions. Hence, it is a snapshot in time, and it does not consider production shifts that may happen between regions due to sudden production losses or price alterations. In other words, our analyses do not reflect changes in demand and import structure.

It does not consider resilience of regions to drought and does not take into account infrastructure, (e.g., salvation irrigation in rain-fed areas, or storage in conditions of water scarcity). The effect of irrigation on water scarcity is not considered in the analysis. We also acknowledge that clear separation between green and blue water footprint and drought severity/water scarcity oversimplifies interaction between rainfall, runoff and surface water flow. Drought conditions, leading to decreased levels of soil 
moisture, may also mean a need for additional irrigation water and potentially increased water scarcity, which can also be translated into vulnerabilities. Another limitation is that we inherit some drawbacks of the water scarcity indicator we have used. The indicator we used did not cover groundwater resources including their interaction and does not account for water storage, water recycling and nor for aquifer discharge. We also acknowledge that water scarcity can be formed of two elements (drivers): Hydrological (water availability) and socio-economic (water withdrawal). Consequently, water scarcity can be result of water insufficiency and/or water mismanagement (overuse) [14,28-30]. These elements may be significant in expressing level of water scarcity, thus vulnerability.

Finally, the approach used in this paper does not reflect upon the political economy consequences linked to virtual water trade [31,32] and the definition of water scarcity as a social construct by the water stakeholders. Our work does not consider the relation between physical availability and reliability of access by all water uses. These elements, social aspects of water use, water productivity, efficiency and consequent water scarcity, are key in achieving Sustainable Development Goal 6 (SDG6), ensuring availability and sustainable management of water.

\section{Conclusions}

Climate change is leading to increased water scarcity and drought in many parts of the world like the Amazon, Southeast Asia, South Asia or North-eastern Brazil. This has implications for the EU because a lot of the goods consumed or used there are produced abroad, and they are susceptible to hydrological extremes. This also makes the EU's economy dependent on water resources well beyond its borders. Our study mapped the dependencies of the EU's economy on water resources outside its borders and assesses its vulnerabilities to drought and water scarcity in relation to this dependency. We found that the EU uses approximately $668 \mathrm{~km}^{3}$ of water for all of the goods it produces, consumes and exports, annually and around $38 \%$ of that water comes from outside its borders. This means that the EU economy is highly dependent on the availability of water in other parts of the world, particularly in Brazil, Argentina, Indonesia, Ivory Coast, Ghana, the United States of America (USA) and India.

Our study also concludes that in the near future, supplies of certain crops to Europe could be disrupted due to water scarcity in other parts of the world; a large portion of the water used in producing soybeans, rice, sugar cane, cotton, almonds, pistachios and grapes for import to the EU comes from areas with significant or severe levels of water scarcity such as India and Pakistan. Although the immediate risks to the EU economy are due to current water scarcity levels, any disruption to rainfall patterns that occurs in the future due to the effects of climate change in the countries of origin of key crops could have a far greater impact on the EU's economy. This is because as much as $92 \%$ of the EU's total external water demand from agriculture is attributed to rain-fed crops. Rainwater is mainly used to produce soybean, cocoa, coffee, oil palm and their derived products.

The EU's economic dependency on goods produced in regions that are vulnerable to water-related impacts can be considered in government policies and business strategies. The strategic importance of regions, such as South-east Asia and South America, will increase for Europe with respect both to potential climate-induced impacts on water resources and to the need for continuous supply of commodities imported from these regions. Investments, such as increasing drought resilience and strengthening water governance to ensure sustainable, efficient and equitable water use, can reduce the vulnerability of the EU's economy.

Author Contributions: Conceptualization, E.E.; methodology, E.E., D.C. and A.K.C.; software, E.E., D.C. and A.K.C.; validation, E.E., D.C. and A.K.C.; formal analysis, E.E., D.C. and A.K.C.; investigation, E.E., D.C. and A.K.C.; resources, E.E., D.C. and A.K.C.; data curation, E.E.; writing-original draft preparation, E.E., D.C. and A.K.C.; writing-review and editing, E.E., D.C. and A.K.C.; visualization, E.E., D.C. and A.K.C.; supervision, E.E.; project administration, E.E.; funding acquisition, E.E.

Funding: This research study was funded by the European Commission under the IMPREX project under to Horizon 2020 framework program (Grant No. 641811).

Acknowledgments: The author Daniel Chico states that this work was not undertaken as part of his responsibilities in the organization CDP. 
Conflicts of Interest: The authors declare no conflict of interest. The funders had no role in the design of the study; in the collection, analyses, or interpretation of data; in the writing of the manuscript, or in the decision to publish the results.

\section{References}

1. Marston, L.; Konar, M. Drought impacts to water footprints and virtual water transfers of the Central Valley of California. Water Resour. Res. 2017, 53, 5756-5773. [CrossRef]

2. Hoekstra, A.Y.; Chapagain, A.K.; Aldaya, M.M.; Mekonnen, M.M. The Water Footprint Assessment Manual: Setting the Global Standard; Earthscan: London, UK, 2011.

3. Leng, G.; Hall, J. Crop yield sensitivity of global major agricultural countries to droughts and the projected changes in the future. Sci. Total Environ. 2019, 654, 811-821. [CrossRef] [PubMed]

4. Chouchane, H.; Krol, M.S.; Hoekstra, A.Y. Virtual water trade patterns in relation to environmental and socioeconomic factors: A case study for Tunisia. Sci. Total Environ. 2018, 613-614, 287-297. [CrossRef] [PubMed]

5. Mekonnen, M.M.; Hoekstra, A.Y. National Water Footprint Accounts: The Green, Blue and Grey Water Footprint of Production and Consumption; Value of Water Research Report Series No. 50; UNESCO-IHE: Delft, The Netherlands, 2011.

6. IPCC. Climate Change 2014: Synthesis Report. Contribution of Working Groups I, II and III to the Fifth Assessment Report of the Intergovernmental Panel on Climate Change; IPCC: Geneva, Switzerland, 2014; p. 151.

7. Chouchane, H.A.Y.; Hoekstra, M.S.; Mekonnen, M.M. The water footprint of Tunisia from an economic perspective. Ecol. Indic. 2015, 52, 311-319. [CrossRef]

8. Duarte, R.; Pinilla, V.; Serrano, A. Long term drivers of global virtual water trade: A trade gravity approach for 1965-2010. Ecol. Econ. 2019, 156, 318-326. [CrossRef]

9. Masud, M.B.; Wada, Y.; Goss, G.; Faramarzi, M. Global implications of regional grain production through virtual water trade. Sci. Total Environ. 2019, 659, 807-820. [CrossRef] [PubMed]

10. Ercin, A.E.; Mekonnen, M.M.; Hoekstra, A.Y. Sustainability of national consumption from a water resources perspective: The case study for France. Ecol. Econ. 2013, 88, 133-147. [CrossRef]

11. Chapagain, A.; Hoekstra, A. The global component of freshwater demand and supply: An assessment of virtual water flows between nations as a result of trade in agricultural and industrial products. Water Int. 2008, 33, 19-32. [CrossRef]

12. Hoekstra, A.Y.; Mekonnen, M.M. The water footprint of humanity. Proc. Nat. Acad. Sci. USA 2012, 109, 3232-3237. [CrossRef] [PubMed]

13. Allan, J.A. Virtual water: A strategic resource, global solutions to regional deficits. Groundwater 1998, 36, 545-546. [CrossRef]

14. Mekonnen, M.M.; Hoekstra, A.Y. Four billion people facing severe water scarcity. Sci. Adv. 2016, 2, e1500323. [CrossRef] [PubMed]

15. ITC. PC-TAS Version 2005-2009 in HS, CD-ROM; International Trade Centre: Geneva, Switzerland, 2010.

16. ITC. PC-TAS Version 2009-2013 in HS, CD-ROM; International Trade Centre: Geneva, Switzerland, 2016.

17. Ercin, A.E.; Hoekstra, A.Y. Water footprint scenarios for 2050: A global analysis. Environ. Int. 2014, 64, 71-82. [CrossRef] [PubMed]

18. Mekonnen, M.M.; Hoekstra, A.Y. The Green, Blue and Grey Water Footprint of Crops and Derived Crop Products; Value of Water Research Report Series No. 47; UNESCO-IHE: Delft, The Netherlands, 2010.

19. FAOSTAT Data. FAOSTAT Online Database; Food and Agriculture Organization of the United Nations: Rome, Italy, 2016.

20. Mekonnen, M.M.; Hoekstra, A.Y. The Green, Blue and Grey Water Footprint of Farm Animals and Animal Products; Value of Water Research Report Series No. 48; UNESCO-IHE: Delft, The Netherlands, 2010.

21. Wheeler, R.O.; Cramer, G.L.; Young, K.B.; Ospina, E. The World Livestock Product, Feedstuff, and Food Grain System: An Analysis and Evaluation of System Interactions throughout the World, with Projections to 1985; Technical Report; Winrock International Livestock Research and Training Center, Petit Jean Mountain: Morrilton, AR, USA, 1981.

22. FAOSTAT Data. Food Balance Sheets; FAO Statistical Databases: Rome, Italy, 2016; Available online: http://faostat.fao.org/site/291/default.aspx (accessed on 12 March 2016). 
23. Gassert, F.; Reig, P.; Shiao, T.; Luck, M. Aqueduct Global Maps 2.1 Indicators, Constructing Decision-Relevant Global Water Risk Indicators, World Resources Institute; Working Paper World Resources Institute: Washington, DC, USA, 2015; Available online: https://www.wri.org/publication/aqueduct-global-maps-21-indicators (accessed on 5 February 2015).

24. Europe Economics. The Economic Impact of the Palm Oil Imports in the EU; Technical Report; Europe Economics: London, UK, 2014.

25. European Commission, EC. Communication from the Commission to the European Parliament, the Council, the European Economic and Social Committee and the Committee of the Regions. Report on the Review of the European Water Scarcity and Droughts Policy. 2012. Available online: https://eur-lex.europa.eu/legal-content/EN/TXT/ ?uri=CELEX:52012DC0672 (accessed on 25 March 2016).

26. Chapagain, A.K.; Orr, S. UK Water Footprint: The Impact of the UK's Food and Fibre Consumption on Global Water Resources Surrey; WWF-UK: Godalming, UK, 2008.

27. Chapagain, A.K.; Orr, S. An improved water footprint methodology linking global consumption to local water resources: A case of Spanish tomatoes. J. Environ. Manag. 2009, 90, 1219-1228. [CrossRef] [PubMed]

28. Hussein Hussam. Whose 'reality'? Discourses and hydropolitics along the Yarmouk River. Contemp. Levant 2017, 2, 103-115. [CrossRef]

29. Hussein Hussam. Lifting the veil: Unpacking the discourse of water scarcity in Jordan. Environ. Sci. Policy 2018, 89, 385-392. [CrossRef]

30. Brown, A.; Matlock, M.D. A Review of Water Scarcity Indices and Methodologies, 19; White Paper; The Sustainability Consortium: Morrilton, AR, USA, 2011.

31. Sojamo, S.; Keulertz, M.; Warner, J.; Allan, J.A. Virtual Water Hegemony: The Role of Agribusiness in Global Water Governance. Water Int. 2012, 37, 169-182. [CrossRef]

32. Zeitoun, M.; Warner, J. Hydro-hegemony-a framework for analysis of transboundary water conflicts. Water Policy 2006, 8, 435-460. [CrossRef]

(C) 2019 by the authors. Licensee MDPI, Basel, Switzerland. This article is an open access article distributed under the terms and conditions of the Creative Commons Attribution (CC BY) license (http://creativecommons.org/licenses/by/4.0/). 